REFLECTIONS:

NEUROLOGY AND

THE HUMANITIES

Section Editor

Anne W. McCammon,

MD, FAAN

Claire J. Creutzfeldt, MD

\title{
Not Just Yet
}

The left side of my body, It feels as if it's dead.

My right side says it's time to go,

But I say, not just yet.

I tell myself I'm ready.

Remove the trach and PEG.

Correspondence \& reprint requests to Dr. Creutzfeldt: clairejc@uw.edu

But when my daughter smiles at me,

I realize, not just yet.

I used to think that no one

Would want to live like that.

Now life and love, just on their own,

Seem worth a not just yet.

My loved ones ask, "Prognosis?"

The doctors palliate.

I look around the room and hear

My silent scream: "Not yet!" 


\title{
Neurology
}

\author{
Not Just Yet \\ Claire J. Creutzfeldt \\ Neurology 2012;79;197 \\ DOI 10.1212/WNL.0b013e31825f0557
}

\section{This information is current as of July 9, 2012}

\section{Updated Information \& Services}

Subspecialty Collections

\section{Permissions \& Licensing}

Reprints including high resolution figures, can be found at: http://n.neurology.org/content/79/2/197.full

This article, along with others on similar topics, appears in the following collection(s):

Palliative care

http://n.neurology.org/cgi/collection/palliative_care

Prognosis

http://n.neurology.org/cgi/collection/prognosis

Stroke in young adults

http://n.neurology.org/cgi/collection/stroke_in_young_adults

Information about reproducing this article in parts (figures,tables) or in its entirety can be found online at:

http://www.neurology.org/about/about_the_journal\#permissions

Information about ordering reprints can be found online:

http://n.neurology.org/subscribers/advertise

Neurology ${ }^{\circledR}$ is the official journal of the American Academy of Neurology. Published continuously since 1951, it is now a weekly with 48 issues per year. Copyright Copyright (? 2012 by AAN Enterprises, Inc.. All rights reserved. Print ISSN: 0028-3878. Online ISSN: 1526-632X.

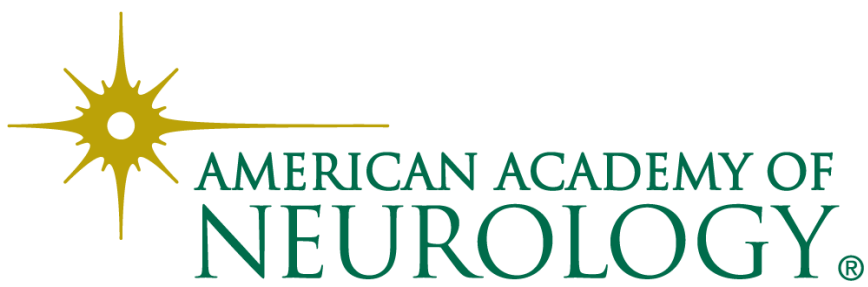

